\title{
Edukasi Pembelajaran Bahasa Indonesia pada Masa Pandemi di SDK Santo Bavo Kota Madiun
}

\author{
* Radian Arum Ardhani \& Lidia Deviga \\ Prodi D3 Perekam dan Informasi Kesehatan \\ STIKES Bhakti Husada Mulia, Indonesia
}

\begin{abstract}
ABSTRAK
Arah dari pembelajaran bahasa Indonesia adalah meningkatkan kesadaran dan kemampuan berbahasa. Kemampuan berbahasa meliputi kemampuan berbicara, menyimak, menulis, dan membaca.Bahasa Indonesia adalah salah satu pelajaran yang dirasa sulit dan menjenuhkan ketika penyampaiannya dilakukan secara daring. Untuk mewujudkan pembelajaran bahasa Indonesia yang menyenangkan dan bisa tersampaikan dengan baik, perlu adanya pemberian edukasi pembelajaran bahasa Indonesia berupa pelatihan penggunaan perbendaharaan kata, kaidah bahasa, dan kaidah tata tulis. Tujuan kegiatan pengabdian ini untuk memberikan edukasi pembelajaran bahasa Indonesia pada siswa di SDK Santo Bavo Kota Madiun dalam menghadapi pembelajaran melalui daring. Dalam edukasi ini, solusi yang ditawarkan adalah memberikan edukasi pembelajaran melalui program pelatihan penguasaan ketrampilan lisan maupun tulisan.Metode Pelaksanaan kegiatan yang digunakan adalah pendampingan. Materi yang diberikan dalam edukasi pembelajaran Bahasa Indonesia meliputi dua hal, yaitu materi lisan berupa perbendaharaan kata dan kaidah bahasa, sedangkan materi tulis berupa kaidah tata tulis.Hasil dari kegiatan ini, siswa mampu menguasai konsep pembelajaran bahasaIndonesia dengan baik serta menerapkan secara efektif dan menyenangkan. Jadi, simpulan kegiatan pengabdian ini mampu meningkatkan antusiasme dan motivasi tinggi siswa terhadap pembelajaran bahasa Indonesia.
\end{abstract}

Kata kunci : Edukasi, Pembelajaran Bahasa Indonesia, Pandemi.

\begin{abstract}
The direction of learning Indonesian is to increase awareness and language skills. Language skills include the ability to speak, listen, write, and read. Indonesian is one of the lessons that is considered difficult and tedious when it is presented online. To realize learning Indonesian that is fun and can be conveyed well, it is necessary to provide Indonesian language learning education in the form of training in the use of vocabulary, language rules, and grammar rules. The purpose of this community service activity is to provide Indonesian language learning education to students in SDK Santo Bavo atthe Madiun City in dealing with online learning.The solution offered is to provide learning education through a training program for mastering oral and written skills. The method of implementing the activities used is mentoring. The method of implementing the activities used is mentoring. The material provided in Indonesian language learning education includes two things, namely oral material in the form of vocabulary and language rules, while written material in the form of written grammar rules. The results is that students are able to master the concept of learning Indonesian well and apply it effectively and fun. The conclusion of this service activity is that it can increase students' enthusiasm and high motivation towards learning Indonesian.
\end{abstract}

Keyword: Education, Indonesian language learning, Pandemic.

* Corresponding Author:

Alamat : Jalan Taman Praja No.25, Mojorejo, Kec. 


\section{PENDAHULUAN}

Arah dari pembelajaran bahasa Indonesia adalah meningkatkan kesadaran dan kemampuan berbahasa karena manusia adalah makhluk yang berbahasa. Chaer (2014:32) mengatakan bahwa Bahasa adalah "sistem lambang bunyi yang arbitrer yang digunakan oleh para anggota kelompok sosial untuk bekerja sama, berkomunikasi dan mengidentifikasi diri." Ini dimaksud bahwa bahasa mempunyai sifat dan ciri yang mana suka. Terlepas dari itu semua, pembelajaran bahasa Indonesia harus sesuai dengan kaidah yang berlaku. Untuk mencapai tujuan tersebut, pembelajaran Bahasa Indonesia harus memenuhi beberapa kriteria yang sesuai dengan standart PUEBI dan KBBI. Kriteria tersebut tidak serta merta bisa digunakan secara langsung tetapi harus melihat konteks dan situasinya. Ratri (2019), menyebutkan faktor penentu tersebut sebagai faktor situasi, yaitu situasi pembicaraan antara pelaku pembicaraan (pembicara dan lawan bicara), konteks, tujuan, tuturan sebagai tindak ujar dan tuturan sebagai produk ujar.

Pada konteks lisan, penyampaian pesan bisa dibantu oleh situasi yang berkaitan dengan latar fisik dan sosial. Sedangkan pada konteks tulis yang mana dalam proses penyampaiannya pembicara tidak hadir di hadapan komunikan. Dalam komunikasi tulis, ada beberapa hal yang perlu diperhatikan salah satunya adalah Bahasa.Bahasa tulis menjadi satu-satunya penghubung antara komunikator (penulis) dengan komunikan (pembicara).Keberhasilan komunikasi tulis salah satunya dipengaruhi oleh penggunaan Bahasa. Pilihan kata dan ketepatan menerjemahkan atau mengartikan kata-kata yang bisa berpengaruh pada penyampaian pesan apakah tepat diterima ataukah menimbulkan kesalahpahaman (Ratri,2019:40). Jadi, bisa dipahami bahwa konteks tulis bisa berjalan dan berhasil jika kaidah Bahasa dan kaidah tata tulis digunakan secara tepat dan baik.

Untuk mewujudkan keberhasilan pembelajaran Bahasa Indonesia yang sesuai dengan PUEBI dan KBBI, maka perlu adanya pemberian edukasi kepada siswa-siswa terutama siswa di SDK Santo Bavo kota Madiun. Menurut Kamus Besar Bahasa Indonesia (2021), edukasi adalah proses pengubahan sikap dan tata laku seseorang atau kelompok orang dalam usaha mendewasakan manusia melalui upaya pengajaran dan pelatihan.Dalam pembelajaran Bahasa Indonesia terutama siswa sekolah dasar perlu adanya pemberian edukasi dalam penerapannya. Ini dikarenakan bahwa pembelajaran bahasa Indonesia cenderung menjadi momok menakutkan bagi mereka ketika implikasinya tidak sesuai dengan gambaran mereka. Siswa cenderung merasa jenuh dan tertekan ketika dihadapkan dengan pembelajaran bahasa Indonesia baik secara langsung maupun melalui media daring.

Masa pandemi sekarang ini, mau tidak mau siswa harus dihadapkan dengan pembelajaran melalui daring. Siswa SDK Santo Bavo kota Madiun sebagai mitra dalam kegiatan pengabdian inimengalami kesulitan ketika mereka harus dihadapkan dengan pembelajaran melalui daring terutama masalah kebahasaan baik itu lisan maupun tulisan. Berdasarkan hasil observasi pada sekolah mitra tersebut terdapat beberapa permasalah yang timbul dalam pelaksanaan pembelajaran Bahasa Indonesia. 
Permasalahan pada pembelajaran Bahasa disekolah tersebut telah teridentifikasi menjadi beberapa hal, yaitu

a. Tingkat keberhasilan belajar siswa rendah, khususnya Bahasa. Hal ini dikarenakan metode pelaksanaan yang digunakan dalam pembelajaran di kelas kurang lebih sama yaitu masih mengandalkan metode ceramah;

b. Minat belajar siswa rendah karena sulitnya pemahaman dalam pembelajran Bahasa.

c. Penerapan model pembelajaran kurang sesuai dengan karakteristik siswa dan materi yang diberikan, serta

d. Tingkat kejenuhan siswa karena penerapan pembelajaran hanya berpusat pada siswa pendengar tanpa variasi model pembelajaran yang menarik.

Dalam identifikasi permasalahan tersebut yang menjadi prioritas utama dalam hal ini adalah siswa, dimana siswa merupakan aktor utama dan menjadi obyek dalam kelas. Siswaakan berperan secara penuh dan secara aktif sehingga pembelajaran akan menjadi hidup. Setelah melakukan observasi dan identifikasi keadaan awal, tim kemudian membuat materi edukasi berupa rincian materi pelatihan dan pengajaran tentang penggunaan bahasa Indonesia yang baik dan benar serta menyusun pelaksanaan kegiatan. Kegiatan ini dilaksanakan selama 4 kali pertemuan. Setiap pertemuan dilaksanakan sekali dalam sepekan, yakni pada hari selasa. Penyusunan jadwal pengabdian disesuaikan dengan jadwal sekolah siswa kelas rendah di SDK Santo Bavo Kota Madiun. Hal ini bertujuan agar siswa datang sesuai jadwal sekolah sehingga tidak mengganggu kelas lain pada hari berbeda. Tujuan kegiatan pengabdian ini adalah untuk memberikan edukasi berupa pelatihan dan pengajaran penggunaan bahasa Indonesia yang baik dan benar kepada setiap peserta didik yang sedang belajar di SDK Santo Bavo Kota Madiun. Lebih jauh tujuan edukasi ini, guna memperkenalkan dan menerapkan bahasa Indonesia kepada peserta didik dengan menarik dan kreatif.

\section{METODE}

Berdasarkan tujuan yang telah dipaparkan di atas, kegiatan pengabdian pada masyarakat yang dilakukan di SDK Santo Bavo Kota Madiundengan para siswa sebagai mitra kegiatan. Pengabdian tersebut berlangsung selama 1 bulan, dimulai pertengahan bulan mei hingga pertengahan bulan juni 2021. Pelatihan ini dilaksanakan pada tiap hari kamis, yang dimulai pukul 14.00-16.30 WIB. Jumlah peserta pelatihan sebanyak 16 orang. Dalam kegiatan pelatihan ini,siswa dibagi menjadi 2 kelompok mengingat situasi dan kondisi pandemi saat ini tidak memungkinkan untuk dijadikan satu dalam kelompok belajar. Kelompok ini terdiri dari siswa kelas rendah dan kelas tinggi. Adapun Metode yang digunakan pada saat pembelajaran adalah sebagai berikut:

a. Kegiatan awal. Tim pengabdian melakukan edukasi atau pengenalan singkat pentingnya penggunaan Bahasa Indonesia.

b. Inti. masuk ke pengajaran dan pelatihan.

c. Terakhir evaluasi. Pada saat edukasi dan pengajaran pelatihanTim menggunakan metode ceramah dengan menggunakan audio visual yang menarikserta memberikan contoh-contoh kata maupun kalimat sederhana, kemudian tim meminta siswa untuk berdiskusi dengan teman-temannya, 
dan terakhir tim memberikan tugas tertulis, yakni membuat kalimat efektif (kalimat yang benar menurut tatanan bahasa Indonesia) dan berbicara menggunakan bahasa yang baik dan santun.

\section{HASIL DAN PEMBAHASAN}

Sebelum memulai pelatihan, tim terlebih dahulu melakukan sosialisasi, observasi dan komunikasi dengan kepala sekolah dan pihak-pihak terkait guna kelancaran kegiatan pengabdian masyarakat ini. Sosialisasi ini dilaksanakan pada hari Selasa, 4Mei 2021. Pihak sekolah mendukung dan mempercayakan penuh rencana kegiatan pelatihan yang akan dilaksanakan. Setelah memperoleh izin dari pihak sekolah khususnya Ibu kepala sekolah, tim bergerak untuk melakukan observasi terkait kondisi awal di lapangan serta melakukan wawancara dengan guru pengajar kelas rendah terkait hal-hal yang akan dibahas pada saat kegiatan pengabdian. Dari hasil observasi dan wawancara dengan guru, ditemukan permasalahan bahwa rata-rata siswa tidak memahami bahasa Indonesia yang baik dan benar, terlebih berkomunikasi dengan bahasa Indonesia yang baik dan benar. Mereka cenderung kesulitan dalam pelafalannya karena masih sering mencampur dengan bahasa asli mereka yaitu bahasa Jawa atau terkadang ada juga yang menyisipkan dengan menggunakan bahasa gaul atau bahasa popular kalangan remaja masa kini. Dalam penulisan masih banyak sekali ditemukan penyusunan kalimat yang kurang sesuai dengan PUEBI maupun KBBI. Siswa juga cepat merasa bosan dan jenuh ketika menerima pembelajaran bahasa dikelas.Berikut adalah gambar SDK Santo Bavo yang di ambil pertama kali pada saat melaksanakan observasi.

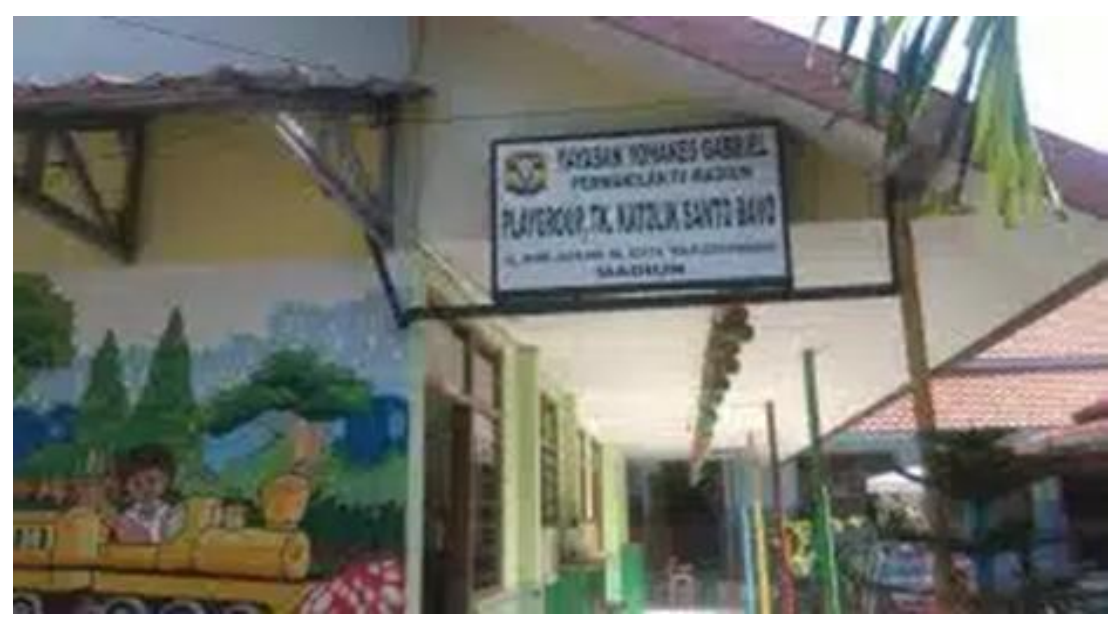

Gambar 1

Gambar Depan SDK Santo Bavo 


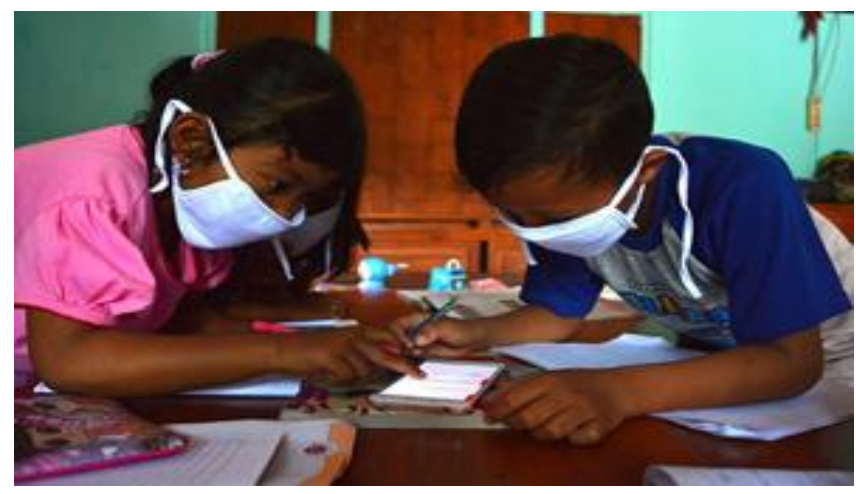

\section{Gambar 2 \\ Pengenalan Pembelajaran Bahasa Indonesia yang Baik (Penerapan pada Komunikasi)}

\section{Edukasi Pembelajaran Bahasa Indonesia Pada Masa Pandemi di SDK Santo Bavo Kota Madiun \\ SDK Santo Bavomerupakan yayasan Khatolik yang ada di Desa Rejomulyo} kecamatan Kartoharjo Kota Madiun. SDK ini terletak di jalan Bumijaya No. 60, Desa Rejomulyo, Kecamatan Kartoharjo, Kota Madiun, Jawa Timur, Dalam proses belajar mengajar, sekolah tersebut menerapkan pola pembelajaran formal yang disesuaikan dengan kurikulum belajar siswa.Para siswa diberikan tambahan jam belajar secara intens dalam keterampilan berbahasa guna melatih kemandirian mereka dan bekal mereka di masa depan.Selain siswa mampu menerapkan Bahasa Indonesia yang baik dan benar, mereka juga dibekali dengan keterampilan berbahasa selain Bahasa Indonesia sebagai hal utama disekolah. Hal lain yang diajarkan di sana adalahBahasa Inggris dan Bahasa Mandarin. Para siswa diajarkan Bahasa Inggris sebab diera yang memasuki ranah 4.0 diharapkan siswa mampu bersaing dan berdaya guna dengan kreatif serta inovatif di masa yang akan dating. Bahasa Indonesia tidak diajarkan semaksimal mungkin, disebabkan karena guru dan pengolala sekolah dalam hal ini kepala sekolahmenganggap para siswa yang pada dasarnya merupakan warga Indonesia asli sudah pasti paham dalam berkomunikasi dengan bahasa Indonesia. Pada hal kenyataannya tidak demikian, para siswaberkomunikasi dengan menggunakan bahasa Indonesia yang tidak baik dan benar bahkan cenderung ke barat-baratan. Dalam kegiatan pengabdian ini, adapun rincian kegiatan tiap-tiap pertemuan akan dijabarkan sebagai berikut.

a. Pertemuan 1. Pertemuan I dilaksanakan pada hari Kamis, tanggal 20 mei 2021. Pada pertemuan I, kegiatan dimulai pada pukul 14.00 WIB. Pertemuan pertama diawali dengan, tim menguji pengetahuan peserta terkait bahasa yang baik dan benar. Hal ini penting untuk mengetahui sejauh mana keberhasilan sebuah pengajaran. Selanjutnya tim melaksanakan edukasi, pembimbingan serta pengenalan bahasa Indonesia yang baik dan tidak baik, benar dan tidak benar, serta perbedaan keduanya. Penyampaian materi ini penting karena memberikan pengetahuan awal tentang bagaimana dan hal- 
hal apa saja yang harus dipahami sebelum mengaplikasikannya di masyarakat.

b. Pertemuan 2. Pada pertemuan II, Kamis, 27 mei 2021 pukul 14.00-16.00 WIB,dilaksanakan pengajaran tentang bahasa yang baik serta pengaplikasiannya dalam bentuk komunikasi. Kegiatan ini bertujuan untuk memberikan soft skill pada siswayang nanti dikemudian hari diharapkan mampu digunakan sebagai bekal di masyarakat. Pada pelaksanaannya, tim pelaksana pengabdian memberikan contoh berbahasa yang baik kepada peserta kegiatan. Selanjutnya tim pengabdian meminta kepada peserta untuk memberikan contoh komunikasi yang baik. Metode ini dilakukan untuk melatih keberanian peserta baik dalam berkomunikasi dengan bahasa Indonesia yang baik di masyarakat serta menumbuhkan motivasi kesadaran berbahasa Indonesia yang baik dan benar. Di akhir pertemuan, tim pengabdian dengan peserta kegiatan melakukan evaluasi dan refleksi terkait dengan kegiatan pelatihan pada hari tersebut.

c. Pertemuan 3. Pertemuan III dilaksanakan pada hari kamis tanggal 3Juni 2021. Waktu pelaksanaan kegiatan ini sama dengan pertemuanpertemuan sebelumnya yaitu dimulai pada pukul 14.00-16.00 WIB. Materi pelatihan pertemuan III yaitu tentang pengajaran bahasa yang benar. Tim memberikan contoh penulisan kalimat efektif yang selanjutnya disebut kalimat yang benar. Kemudian,tim meminta peserta untuk membuat kalimat-kalimat efektif, merangkai kalimat-kalimat tersebut menjadi cerita pengalaman yang menarik dan setelah selesai pengerjaan timakan memeriksa hasil tulisan siswa. Di akhir pertemuan, tim bersama dengan peserta melakukan refleksi dari hasil kegiatan tersebut.

d. Pertemuan 4. Pelaksanaan pertemuan IV yang sekaligus merupakan pertemuan terakhir dilaksanakan pada hari Kamis, 10 Juni 2021 pukul 14.0016.00 WIB. Tim melaksanakan evaluasi akhir pada peserta pengabdian tentang pemahamannya mengenai bahasa Indonesia yang baik dan benar. Hasil akhir yang tampak adalah bahwa peserta mulai memahami perbedaan bahasa yang baik dan bahasa yang benar, serta mampu menerapkandalam berkomunikasi secara lisan maupun tertulis. Akan tetapi masih sedikit ditemukan kesalahan pada tulisan peserta saat menulis kalimat yang benar. Hal ini dirasa wajar, sebab pertemuan yang singkat dan penyampaian materi yang ringkas membuat peserta sedikit kesulitan dalam membedakan kalimat yang baik dan benar pada tulisan.

\section{SIMPULAN}

Kegiatan pengabdian masyarakat yang berlangsung selama 4 kali pertemuan dalam 1 bulan ini dinilai berhasil, peserta mengalami kemajuan dari pengetahuan peserta serta mampu menerapkannya dalam komunikasi lisan maupun tulisan tentang bahasa yang baik dan benar yang selama ini mereka pahami. Hasil akhir yang terlihat adalah peserta mulai memahami perbedaan bahasa yang baik dan bahasa yang benar, serta penerapannya dalam berkomunikasi baik lisan maupun tulisan. Akan tetapi masih ditemukan sedikit kesalahan pada tulisan peserta pada saat menulis kalimat yang benar. Hal ini 
dirasa wajar, sebab pertemuan yang singkat dan penyampaian materi yang ringkas membuat siswa sedikit kesulitan dalam membedakan kalimat yang baik dan benar pada tulisan. Saran dari tim masih dirasa perlu untuk melaksanakan pengabdian lanjutan, untuk memberikan waktu lebih banyak pada siswa dalam melakukan tanya jawab mengenai bahasa Indonesia yang baik dan benar, sehingga siswa dalam pengaplikasian dan pemahaman tidak keliru ketika nanti diterapkan langsung di masyarakat. Hal lain yang diharapkan adalah siswa sebagai generasi muda yang akan dating merupakan obyek yang dikembangkan secara langsung sebagai perpanjangan informasi edukasibahasa Indonesia yang baik dan benar pada masyarakat setempat. Tim merasa perlu untuk melaksanakan pengabdian lanjutan, untuk memberikan waktu lebih banyak pada siswamelakukan tanya jawab mengenai bahasa Indonesia yang baik dan benar, sehingga siswa tidak keliru dalam mengaplikasikan ilmu yang didapat di masyarakat. Hal lain yang diharapkan adalah siswa sebagai generasi muda yang akan dating merupakan obyek yang dikembangkan secara langsung sebagai perpanjangan informasi edukasibahasa Indonesia yang baik dan benar pada masyarakat setempat.

\section{DAFTAR PUSTAKA}

Chaer, Abdul. (2014). Linguistik Umum. Jakarta: Rineka Cipta.

Ratri, Rose Kusumaning. (2019). Cakap Berbahasa Indonesia.Yogyakarta: Ar-Ruzz Media.

http://repository.umy.ac.id/bitstream/handle/123456789/21813/6.\%20BAB\%2 0II.pdf?sequence=6\&isAllowed=y. Diakses pada 30 Juli 2021. 